\title{
Genetic variation of Norway spruce clones regarding their natural durability, physical and chemical properties
}

\author{
Ilze Irbe $^{1}$, Guna Noldt ${ }^{1}$, Uldis Grinfelds ${ }^{1}$, Anrijs Verovkins ${ }^{1}$, Aris Jansons ${ }^{2}$, Gerald Koch $^{3}$ \\ ${ }^{1}$ Latvian State Institute of Wood Chemistry (LS IWC), Riga, Latvia \\ ${ }^{2}$ Latvian State Forest Research Institute "Silava", Salaspils, Latvia \\ ${ }^{3}$ Johann Heinrich von Thunen-Institute (vTI)/Federal Research Institute for Rural Areas, Forestry and Fisheries Institute of Wood \\ Technology and Wood Biology (HTB), Hamburg, Germany \\ Email: ilzeirbe@edi.lv
}

Received 2 September 2012; revised 11 October 2012; accepted 15 November 2012

\begin{abstract}
Genetic variation of ten Norway spruce (Picea abies (L.) Karst.) clones regarding their decay resistance against brown rot fungi, as well as physical and chemical properties of clones were investigated. 31year-old spruce clones: 26, 31, A10, A15, A7, B10, B15, B6, V7, V9 were selected across Latvia. The stem diameters of spruce clones varied between 13.0 and $20.9 \mathrm{~cm}$. The wood density of clones ranged from 361 to $443 \mathrm{~kg} / \mathrm{m}^{3}$. Klason lignin content, depending on the clone, was between $27.0 \%-28.9 \%$. Cellular UV microspectrophotometry of the non-infected tracheids displayed the typical lignin distribution with highest absorbance values in the cell corners $\left(\operatorname{abs}_{280} \mathrm{~nm} \mathbf{0 . 8 0}\right)$ and compound middle lamellae $\left(\operatorname{abs}_{280} \mathrm{~nm} 0.48\right)$, while secondary wall showed lower lignin absorbance values $\left(\mathrm{abs}_{280 \mathrm{~nm}} 0.29-0.35\right)$. The deposition of phenolic extractives in ray parenchyma and epithelial cells of resin canals were emphasized by a significantly higher UV-absorbance $\left(a^{28 b_{28}} \mathrm{~nm} 0.68\right.$ to 0.78$)$ when compared to the cell wall associated lignin. The content of acetone-soluble extractives of spruce clones varied between $1.1 \%-1.8 \%$. The $x$-value (natural durability) for all spruce clones after exposure to $C$. puteana and $P$. placenta was $>0.90$ (durability class 5 , not durable). Most of clones after degradation by $G$. trabeum had $x$-value $>0.90$ with exception of clones B15 and V9 that showed $x$-value $\leq 0.90$ (durability class 4 , slightly durable). Natural durability of spruce clones did not correlate with stem diameter, density, content of lignin and extractives.
\end{abstract}

Keywords: Norway Spruce Clones; Natural Durability; Brown Rot; Lignin; Extractives; Density; UV Microspectrophotometry

\section{INTRODUCTION}

The end use of timber in exterior or interior constructions is determined by its natural durability i.e. inherent resistance to fungal degradation. Brown rot fungi are generally considered the most important rot type for wood in service. They cause an extensive degradation of holocellulose in wood, whilst the lignin fraction is mainly demethylated and depolymerised [1-4]. Lignin is supposed [5] to improve the durability of wood against microbial attack by coating and protecting the cellulose microfibrils.

It has been reported that the natural durability of wood is affected by the density and content of extractives. It was found [6] that oak heartwood with the narrowest growth rings and consequently lower density was more susceptible to fungal decay than denser wood made of wider growth rings. In its turn, phenolic extractives increased decay resistance of e.g., European oak [7], larch heartwood [8] and black locust [9]. The concentration of stilbenes improved decay resistance of Scots pine heartwood [10] while no detectable amounts of stilbenes were found in the heartwood of spruce [11].

Moisture content, temperature, and the relative humidity are considered [12] as more important factors for fungal establishment in wood than the content of main structural components and the amount and composition of extractives. The optimum moisture content for wood decay has been reported between $30 \%$ and $80 \%$ for most rot fungi [13]. Moisture is often recognized as a key factor regarding the long time performance of wooden products, and one of the main challenges for timber products is to predict accurate service life in hazard classes 3 (not covered above ground) and 4 (in soil or fresh water contact) according to EN 335-1 [14]. Investigation on natural durability of wood in different environments in Northern Europe confirmed a higher decay risk in use class 4 than in use class 3 [15], and higher decay risk in a humid climate (Western Norway) than in a dry climate (Eastern Norway).

Proportion of sapwood and heartwood varies according to species, age of trees, growth rate, and environ- 
mental conditions [16]. Sapwood is gradually converted to inactive heartwood as the tree matures [17]. Important changes during conversion of sapwood into heartwood include deposition of extractives, increase in pit aspiration, changes in moisture content etc. [18]. Previous studies $[19,20]$ demonstrated that an important factor for improved natural durability of pine in above ground conditions is whether the timber consists of heartwood or of sapwood. Spruce, in contrast to pine, has traditionally been regarded as a homogenous species without differences in properties between heartwood and sapwood.

EN 350 [21] describes the principles of testing and classification of the natural durability of wood (Part 1) and lists the natural durability and treatability of selected wood species (Part 2). The standard provides data on performance of the heartwood of the species in ground contact (service conditions for hazard class 4, EN 335-1 [14]). If wood is to be used in other hazard classes, the service conditions may result in a performance which differs from that given in EN 350 [21]. It was proposed [22] that laboratory tests, for example, European standard EN 113 [23], are good as screening tests to obtain a fast first opinion about a new species or treatment.

The objective of this study was to determine whether genetic variation of Norway spruce clones influences decay resistance, and whether wood biodegradation is affected by the physical and chemical properties of spruce wood. Evaluation of natural durability of spruce clones would allow recommending the wood for the most appropriate end-use.

\section{MATERIALS AND METHODS}

\subsection{Wood Material}

Ten Norway spruce (Picea abies (L.) Karst.) clones: 26, 31, A10, A15, A7, B10, B15, B6, V7, V9, represented by 3 clonal copies (ramets) on the average, were collected in the 2010, at the age of 31 year, in clonal trial on former agricultural land. Experiment No. 51 (registered in Database of long term forest experiments in Latvia) includes altogether 80 Norway spruce clones from plus trees located across Latvia. It was started in year 1975 with establishment of mother-plant collection and preparation of grafts. Rooting of grafts has been finalized and trial planted in year 1983 with spacing $2 \times 2 \mathrm{~m}$, no thinning was carried out prior to collection of material. Sample trees were selected from most productive clones and 2 slower growing ones (V9, A15) with the aim to represent the diameter distribution in trial, not necessarily the mean of each clone. Only the trees without spike knots, stem cracks or other defects were selected.

\subsection{Sapwood-Heartwood Differentiating}

For sapwood-heartwood differentiating Bromcresol- green solution was prepared as follows: $25 \mathrm{mg}$ Bromcresolgreen was mixed with $0.36 \mathrm{ml} 0.1 \mathrm{~N} \mathrm{NaOH}$ and 10 $\mathrm{ml} \mathrm{96 \%} \mathrm{Ethanol.} \mathrm{The} \mathrm{mixture} \mathrm{was} \mathrm{dissolved} \mathrm{in} \mathrm{water} \mathrm{up}$ to $50 \mathrm{ml}$. According to [24], the heartwood colours blue, and sapwood yellow-green.

\subsection{Wood Density}

Wood density was determined according to the DIN standards [25,26]. Wood samples of size $20 \times 20 \times 10$ $\mathrm{mm}^{3}$ were cut and conditioned at $20^{\circ} \mathrm{C} \pm 2^{\circ} \mathrm{C}$ and $65 \% \pm$ $5 \%$ RH until constant weight. Samples were weighed on a balance with a $0.0001 \mathrm{~g}$ precision. The size of samples was determined to $0.01 \mathrm{~mm}$, using an electronic calliper. The density was expressed as $\mathrm{kg} / \mathrm{m}^{3}$. In total 14 samples were measured for each tree (ramet).

\subsection{Determination of Lignin}

Lignin was determined using $72 \%$ sulphuric acid (Klason method). The wood meal $(1 \mathrm{~g})$ was treated with $15 \mathrm{ml}$ $72 \%$ sulphuric acid (density 1.6). After standing for $2 \mathrm{~h}$ at $25^{\circ} \mathrm{C}$ with occasional stirring, the mixture was diluted with $200 \mathrm{ml}$ distilled water and refluxed for $1 \mathrm{~h}$. The lignin was then filtered and washed free of acid, dried at $105^{\circ} \mathrm{C}$, and weighed [27].

\subsection{Acetone-Soluble Wood Extractives}

$10 \mathrm{~g}$ of wood sawdust particles (less than $0.40 \mathrm{~mm}$ ) were extracted with pure acetone in Soxhlet extraction apparatus. Evaporation was made by vacuum evaporation unit and extractives were dried at $105^{\circ} \mathrm{C}$ and weighed [28].

\subsection{Cell Wall UV Microspectrophotometry (UMSP)}

For the UV-spectroscopic studies parallel sample blocks $\left(1 \times 1 \times 5 \mathrm{~mm}^{3}\right)$ from seven spruce clones and one 80 year old spruce (mature wood) as control sample were prepared, dehydrated and embedded in Spurr's epoxy resin [29] under vacuum conditions. Semi-thin transverse sections $(1 \mu \mathrm{m})$ were transferred to quartz microscope slides, immersed in a drop of non-UV-absorbing glycerine and covered with a quartz cover slip for the topochemical analyses of lignin and phenolic extractives within cell walls and cell lumina according to [30].

The investigations were carried out using a ZEISSUMSP 80 microspectrophotometer equipped with a scanning stage, which enables the determination of UV-images profiles at the constant wavelengths, e.g. for conifer wood lignin at the absorbance maximum of $280 \mathrm{~nm}$.

The semi-thin sections were studied by means of point measurements with a spot size of $1 \mu \mathrm{m}^{2}$ between $240 \mathrm{~nm}$ and $700 \mathrm{~nm}$ wavelength in order to characterize the UVabsorbance of lignin and phenolic extractives. 
In addition, specimens were scanned with a defined wavelength of $280 \mathrm{~nm}$ using the scan program APAMOS (ZEISS). This program digitises rectangular fields of the tissue with a local geometrical resolution of $0.25 \mu \mathrm{m} \times$ $0.25 \mu \mathrm{m}$ and yields a photometric resolution of 4096 grey scales, which are converted into 14 basic colours to visualise the absorbance intensities of individual cell types and cell wall layers [31]. The scans were depicted as two- and three-dimensional image profiles with statistical evaluation of the UV-absorbance values.

\subsection{Wood Decay Test}

The natural durability of spruce clones was determined according to the EN 350 [21]. Spruce specimens $(50 \times 25$ $\times 15 \mathrm{~mm}^{3}$ ) were exposed to the brown-rot fungi Coniophora puteana (Schum.: Fr.) Karst. (BAM Ebw.15), Postia placenta (Fr.) Lars et Lomb. (FPRL 280) and Gloeophyllum trabeum (Pers.: Fr.) Murr. (BAM Ebw.109) on a medium containing 5\% malt extract concentrate and 3\% Fluka agar (Sigma-Aldrich) in Kolle flasks. Scots pine sapwood specimens were used as a reference material. The test procedures of the European standard EN 113 [23] were followed. Sterile wood specimens were aseptically placed on 3-mm glass supports and incubated at $22^{\circ} \mathrm{C}$ and $70 \%$ relative humidity for 16 weeks. Four replicates from each tree (ramet) were taken. Subsequent to cultivation, the specimens were removed from the culture vessels, brushed free of mycelium and oven dried at $103^{\circ} \mathrm{C} \pm 2^{\circ} \mathrm{C}$. The weight loss (\%) was calculated from the dry weight before and after the test.

The durability class was determined according to the $\mathrm{x}$-values calculated from the weight loss of test specimens and reference specimens. Based on $\mathrm{x}$-values, five durability classes (from class 1 as "very durable" to class 5 as "not durable") have been used for wood resistance against fungal degradation.

\subsection{Statistical Analysis}

Statistical software (SPSS 17.0) was applied for estimating descriptive statistics. Analysis of variance (ANOVA) was used to detect the differences among spruce clones regarding fungal degradation. Correlation between natural durability of spruce clones and their physical and chemical properties was determined. The level of significance $\mathrm{p} \leq 0.05$ was applied in all cases.

\section{RESULTS}

\subsection{Physical and Chemical Properties of Spruce Clones}

The stem diameters of the selected spruce clones varied between 13.0 and $20.9 \mathrm{~cm}$ (Table 1). Staining of spruce stems with Bromcresolgreen did not show pronounced sapwood-heartwood boundary.

The wood density ranged from 361 to $443 \mathrm{~kg} / \mathrm{m}^{3}$. In the present study the highest lignin content i.e. $28.9 \%$ was determined for clone B6. The content of wood extractives ranged from $1.1 \%$ to $1.8 \%$ depending on the individual clones.

Clone 31 demonstrated the highest values of stem diameter $(20.9 \mathrm{~cm})$ and content of extractives $(1.8 \%)$ as well as the lowest density $\left(361 \mathrm{~kg} / \mathrm{m}^{3}\right)($ Table 1$)$. Significant negative correlation $(\mathrm{p}<0.01)$ was determined only between wood density and stem diameter. Other tree parameters shown in Table 1 did not correlate with each other.

Table 1. Average values of wood diameter, density, content of lignin and acetone-soluble extractives of Norway spruce clones.

\begin{tabular}{|c|c|c|c|c|c|}
\hline Spruce clone & $\begin{array}{l}\text { Number } \\
\text { of ramets }\end{array}$ & $\begin{array}{l}\text { Mean diameter } \\
(\mathrm{cm})\end{array}$ & $\begin{array}{l}\text { Density } \\
\left(\mathrm{kg} / \mathrm{m}^{3}\right)\end{array}$ & $\begin{array}{l}\text { Lignin } \\
(\%)\end{array}$ & $\begin{array}{c}\text { Extractives } \\
(\%)\end{array}$ \\
\hline A7 & 2 & 15.3 & $405.8 \pm 6.4$ & $28.5 \pm 0.3$ & $1.2 \pm 0.1$ \\
\hline A 10 & 3 & 16.9 & $432.6 \pm 11.2$ & $27.0 \pm 0.2$ & $1.5 \pm 0.2$ \\
\hline A15 & 2 & 15.1 & $408.3 \pm 37.9$ & $27.5 \pm 0.2$ & $1.4 \pm 0.1$ \\
\hline B6 & 3 & 17.1 & $399.1 \pm 24.9$ & $28.9 \pm 0.4$ & $1.6 \pm 0.2$ \\
\hline $\mathrm{B} 10$ & 3 & 17.9 & $406.3 \pm 12.8$ & $28.0 \pm 0.4$ & $1.4 \pm 0.2$ \\
\hline B15 & 3 & 16.9 & $408.5 \pm 21.4$ & $28.3 \pm 0.3$ & $1.1 \pm 0.1$ \\
\hline V7 & 3 & 17.5 & $388.1 \pm 30.2$ & $27.9 \pm 0.3$ & $1.2 \pm 0.1$ \\
\hline V9 & 2 & 13.0 & $443.1 \pm 29.7$ & $27.6 \pm 0.3$ & $1.7 \pm 0.7$ \\
\hline 26 & 3 & 18.3 & $394.5 \pm 33.3$ & $27.8 \pm 0.3$ & $1.3 \pm 0.1$ \\
\hline 31 & 2 & 20.9 & $361.1 \pm 7.4$ & $27.9 \pm 0.6$ & $1.8 \pm 0.4$ \\
\hline
\end{tabular}




\subsection{Topochemical Detection of Lignin and Extractives (UMSP)}

Figure 1 represents typical two- and three-dimensional UV-image profiles of the lignin distribution within the individual cell wall layers of latewood tracheids from the spruce clones. The UV-image profiles of the tracheids displayed the typical lignin distribution with highest absorbance values in the cell corners $(C C)\left(a_{280} \mathrm{~nm} 0.80\right)$ and compound middle lamellae (CML) $\left(\mathrm{abs}_{280 \mathrm{~nm}} 0.48\right)$. The adjacent secondary wall (S2) layers showed a lower, slightly varying lignin distribution $\left(\mathrm{abs}_{280 \mathrm{~nm}} 0.29\right.$ - 0.35).

Typical lignin UV-absorbance spectra of S2 layer (Figure 2), CML and CC (Figure 3), as well as deposits of phenolic extractives in ray parenchyma (Figure 4) were measured in the tissue of different spruce clones. The UV-spectra of the S2 and CML revealed the typical absorbance behaviour of a softwood lignin with a distinct maximum at $280 \mathrm{~nm}$ and a local minimum at about 250 nm.

In comparison to the lignin content of mature wood in $\mathrm{S} 2$ with $\mathrm{abs}_{280 \mathrm{~nm}}$ of 0.37 , the highest value was semiquantitatively recorded in the clone V9 $\left(\mathrm{abs}_{280 \mathrm{~nm}} 0.41\right)$ and the lowest value in clone V7 $\left(\mathrm{abs}_{280 \mathrm{~nm}} 0.31\right)$.

The UV-spectra of the CML revealed maximum absorbance values of $\mathrm{abs}_{280 \mathrm{~nm}} 0.48$ for mature wood and the clone B10 (lowest value) and $\mathrm{abs}_{280 \mathrm{~nm}} 0.62$ for the clone V9 (highest value).
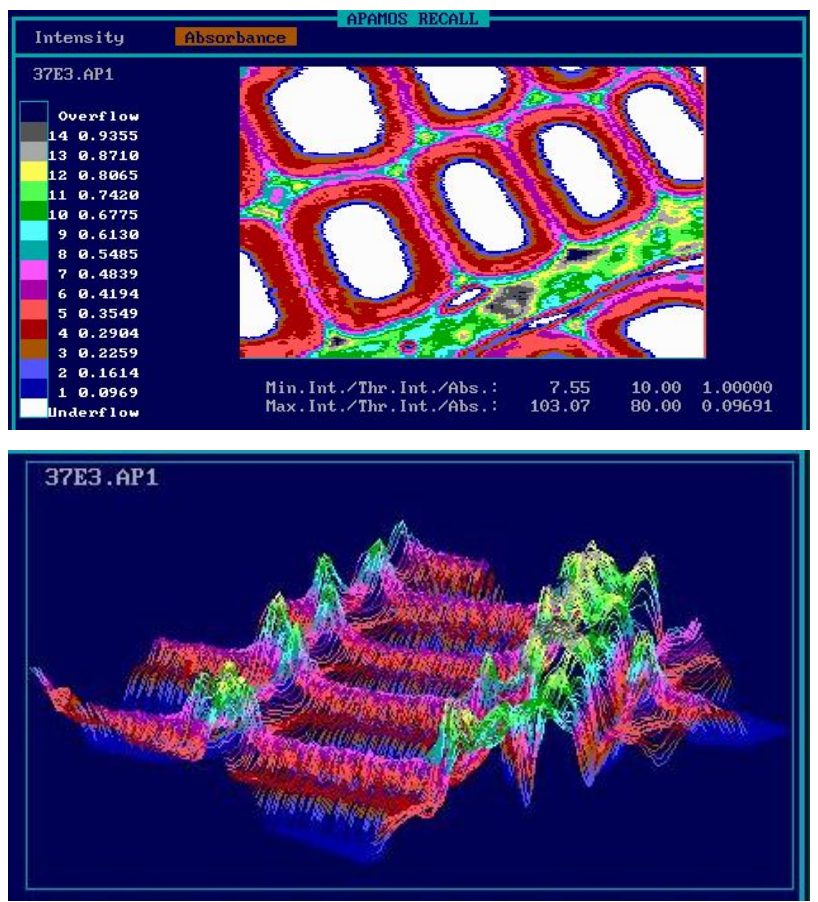

Figure 1. Representative UV microscopic scanning profile of individual cell wall layers and ray parenchyma of Norway spruce clones (size of the scanning area: $53.25 \times 48.00 \mu \mathrm{m}=$ 41302 Pixel or measuring points).

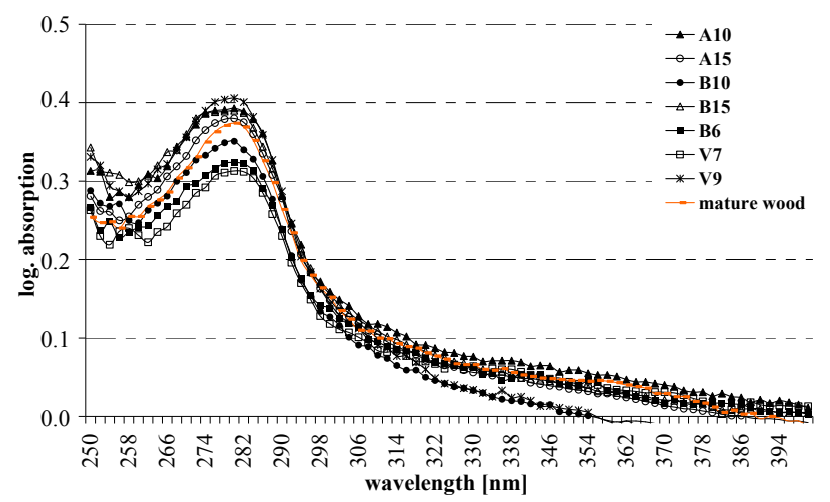

Figure 2. Representative lignin UV absorbance spectra of S2 layer of clonal spruce tracheids compared to mature wood.

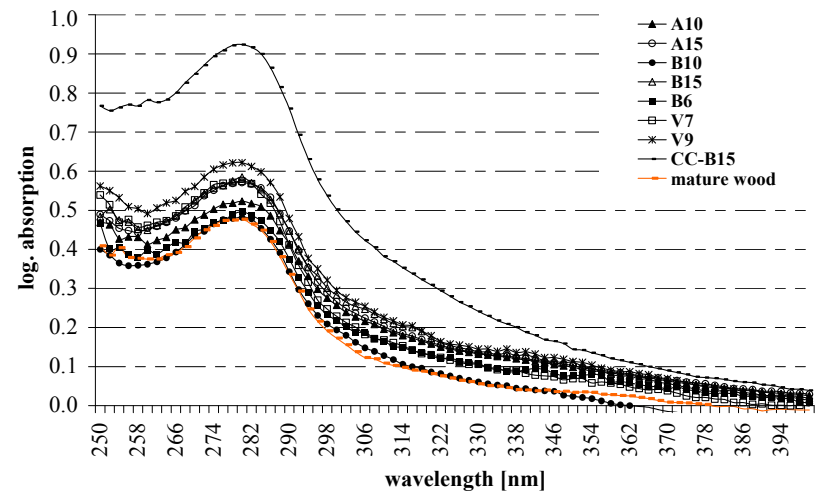

Figure 3. Representative lignin UV absorbance spectra of compound middle lamella (CML) and cell corner (CC) of clonal spruce tracheids.

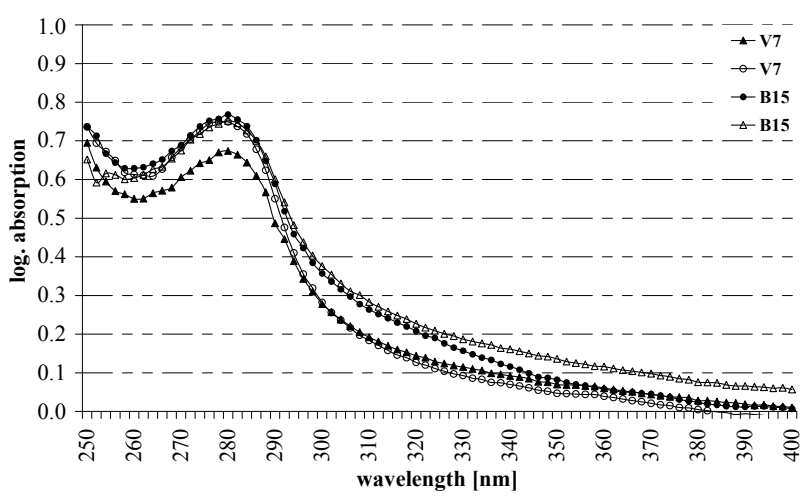

Figure 4. Representative UV absorbance spectra of deposits in ray parenchyma cells of clonal spruce.

Scanning UV microspectrophotometry was used to detect and quantify phenolic extractives topochemically. The presence of the extractives was visualised as local areas of high UV-absorbance in contrast to the surrounding tissue. The deposition of phenolic extractives in ray parenchyma (Figure 1) and epithelial cells (Figure 5) of a resin canal was emphasized by a significantly higher UV-absorbance $\left(\mathrm{abs}_{280 \mathrm{~nm}} 0.68\right.$ to 0.78 ) as compared to the cell wall associated lignin. 

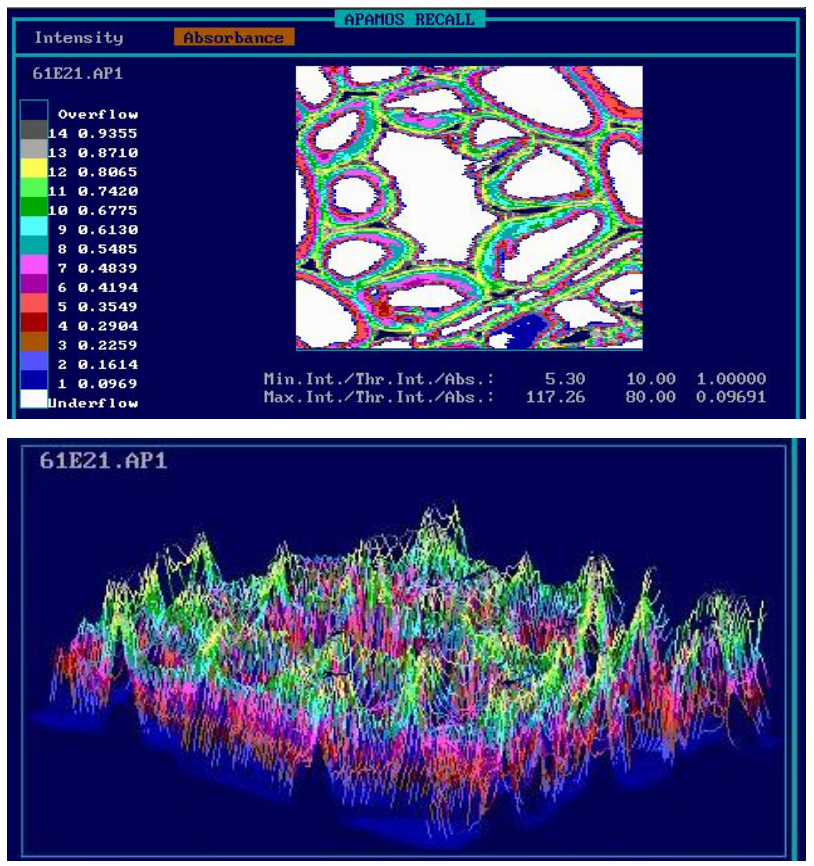

Figure 5. UV microscopic scanning profiles of epithelial cells of a resin canal (two- and three dimensional profiles (size of the scanning area: $56.75 \times 68.25 \mu \mathrm{m}=62472$ Pixel or measuring points).

\subsection{Natural Durability of Spruce Clones}

The highest weight loss of all spruce clones was caused by Coniophora puteana followed by Postia placenta and Gloeophyllum trabeum (Table 2). The highest weight loss $(56.5 \%)$ after exposure to C. puteana showed clone 31 , while the lowest value (49.2\%) was detected for clone V9. P. placenta most intensively degraded clone A10, reaching the wood weight loss of $43.5 \%$, while the lowest weight loss $(35.0 \%)$ showed clone A15. G. trabeum caused the highest weight loss to clone 26, while the least degraded clone was V9 $(32.2 \%)$. Scots pine specimens used as a reference material were extensively degraded reaching weight loss more than $30 \%$ depending on the fungus (Table 2). This indicated that fungal strains were virulent according to the EN 113 [23].

The moisture content of spruce specimens after the durability test varied between $31 \%$ and $73.3 \%$ (Table 2). Moisture of pine control reached more than $47 \%$ that confirmed the characteristic favourable conditions for fungal decay.

The weight losses of spruce specimens were re-calculated as $\mathrm{x}$-values, which demonstrated natural durability of wood according to the EN 350-1 [21] (Table 3). The $\mathrm{x}$-value for all spruce clones after exposure to C. puteana

Table 2. Mean weight loss of the Norway spruce specimens after degradation by brown rot fungi Coniophora puteana (C. p.), Postia placenta (P. p.) and Gloeophyllum trabeum (G. t.).

\begin{tabular}{|c|c|c|c|c|c|c|c|}
\hline \multirow{2}{*}{ Spruce clone } & \multirow{2}{*}{ Number of specimens ${ }^{\mathrm{a}}$} & \multicolumn{3}{|c|}{ Mean weight loss (\%) } & \multicolumn{3}{|c|}{ Mean moisture content, $\mathrm{W}_{\mathrm{abs}}(\%)$} \\
\hline & & C. p. & P. p. & G. t. & C.p. & P. p. & G. t. \\
\hline A7 & $8(2 \times 4)$ & 52.4 & 40.3 & 34.2 & 73.3 & 47.0 & 57.1 \\
\hline A10 & $12(3 \times 4)$ & 54.1 & 43.5 & 33.4 & 64.4 & 42.8 & 57.6 \\
\hline A15 & $8(2 \times 4)$ & 53.5 & 35.0 & 33.6 & 65.0 & 31.0 & 62.3 \\
\hline B6 & $12(3 \times 4)$ & 54.9 & 43.2 & 35.4 & 66.2 & 33.4 & 67.0 \\
\hline $\mathrm{B} 10$ & $12(3 \times 4)$ & 54.8 & 41.5 & 34.0 & 65.2 & 32.2 & 67.8 \\
\hline V7 & $12(3 \times 4)$ & 52.6 & 41.1 & 34.9 & 54.4 & 48.3 & 59.3 \\
\hline V9 & $8(2 \times 4)$ & 49.2 & 41.1 & 32.2 & 56.1 & 39.5 & 56.4 \\
\hline 26 & $12(3 \times 4)$ & 53.5 & 39.7 & 35.9 & 63.5 & 40.7 & 68.1 \\
\hline 31 & $8(2 \times 4)$ & 56.5 & 41.1 & 34.8 & 56.1 & 37.3 & 56.2 \\
\hline Pine control & 104 & 54.2 & 36.9 & 36.6 & 67.0 & 53.2 & 47.5 \\
\hline
\end{tabular}

${ }^{\mathrm{a}}$ Number of specimens (number of trees $\times$ number of specimens per tree).

Table 3. Natural durability, expressed as x-value, of Norway spruce clones against brown-rot fungi.

\begin{tabular}{cccc}
\hline Spruce clone & $\begin{array}{c}\text { Coniophora puteana } \\
\text { x-value }\end{array}$ & $\begin{array}{c}\text { Postia placenta } \\
\text { x-value }\end{array}$ & $\begin{array}{c}\text { Gloeophyllum trabeum } \\
\text { x-value }\end{array}$ \\
\hline A7 & 0.97 & 1.09 & 0.94 \\
A10 & 1.00 & 1.18 & 0.91 \\
A15 & 0.99 & 0.95 & 0.92 \\
B6 & 1.01 & 1.17 & 0.97 \\
B10 & 1.01 & 1.12 & 0.93 \\
B15 & 0.98 & 1.15 & 0.90 \\
V7 & 0.97 & 1.12 & 0.93 \\
V9 & 0.91 & 1.12 & 0.88 \\
26 & 0.99 & 1.08 & 0.98 \\
31 & 1.04 & 1.12 & 0.95 \\
\hline
\end{tabular}


and $P$. placenta was higher than 0.90 that corresponds to the natural durability class 5 (not durable). Most of spruce clones after attack by $G$. trabeum had x-value higher than 0.90 with exception of clones B15 and V9 that showed $\mathrm{x}$-value $\leq 0.90$ (durability class 4 , slightly durable). There was no correlation between stem diameters and $\mathrm{x}$-values.

\section{DISCUSSION}

Physical and chemical properties of individual Norway spruce clones did not influence wood biodegradation intensity. Correlation was not found between stem diameter groups and durability. The density of clones in general was lower (Table 1) than that given in the EN $350-2$ [21], namely, 440 to $470 \mathrm{~kg} / \mathrm{m}^{3}$. The lower values could be explained with the juvenile age of spruce clones used in this study. Density did not correlate with the natural durability. This is in agreement with EN 350-2 [21] which indicated that no clear correlation exists between density and natural durability. Also Bergstrom et al. [32] established that annual ring width and density have no direct influence on durability or moisture uptake neither for spruce nor pine. Besides, it was found [20,32] that also the origin of trees had no direct influence on wood durability or moisture dynamics.

Lignin content of spruce clones was similar (Table 1) to that reported by Fengel and Wegener [33], i.e. 27.3\%. We did not find correlation between lignin content and durability of spruce wood. This is in agreement with the previous study of Harju et al. [34] where juvenile heartwood of 34-years-old Scots pine did not show any significant difference in the concentration of lignin between the decay resistant and susceptible trees. The authors assume that the concentration of total phenolics, acetone-soluble extractives and pinosylvin affected decay resistance of pine heartwood.

The UV-image profiles of the spruce tracheids displayed the highest lignin concentration in the $\mathrm{CC}$, followed by CML and S2 layer (Figure 1). Corresponding to the former studies by Lange [35] and Fergus et al. [36], the average lignin concentration in the cell corners was about twice than that in the secondary wall of the tracheids. S2, CC and CML of spruce tracheids revealed typical lignin absorbance with a distinct maximum at 280 nm (Figures 2 and 3). The maximum absorbance at 280 $\mathrm{nm}$ usually indicates the presence of the strongly absorbing guaiacyl-lignins [37-39].

In detail, the detected UV-absorbance values (range from $\mathrm{abs}_{280 \mathrm{~nm}} 0.31$ to $\mathrm{abs}_{280 \mathrm{~nm}} 0.40$ ) showed some natural variation in the amount of lignin among the spruce clones. According to the earlier studies [30,31,40,41], this spectral variation is typical for the S2 layers of spruce tracheids and does not differ from the spectral behaviour of normal-growth spruce trees. The absorbance spectra of the CML revealed a slightly varying lignin distribution $\left(a_{280} \mathrm{~nm} 0.48\right.$ - 0.62) with significant higher absorbance values as compared to the S2. Total Klason lignin content of Norway spruce clones varied between $27.0 \%$ and $28.9 \%$ (Table 1). Against the results of our topochemical and microscopic analyses, a study by Saranpää et al. [42] revealed that cell walls of clonal, fast-growing Norway spruce are relatively thin. A large proportion of the tracheid cell wall was formed by the middle lamella, and hence the wood has higher lignin content. Fagerstedt et al. [43] has found, that fast-grown trees on the more fertile soils were characterised by a higher concentration of lignin as compared to slowergrown trees.

Content of acetone-soluble extractives in spruce clones was lower (Table 1) than shown previously. According to Fengel and Wegener [33] Norway spruce contained $2.2 \%$ of extractives. This difference could be attributed to the younger age of spruce clones of this study. Correlation was not determined between content of extractives and resistance against fungal attack. Duenisch et al. [9] studied the role of extractives of black locust against fungal degradation and found that juvenile wood after degradation by Coniophora puteana and Trametes versicolor revealed the mean weight loss of $10.1 \%$ and $17 \%$, respectively, that conformed to EN 350 [21] durability class 2 - 4 (resistant to slightly resistant). The authors concluded that the juvenile wood of black locust had a lower natural durability than the mature wood (durability class 1 , highly resistant) due to lower content of extractives in the juvenile wood. However, the content of acetone-soluble extractives in the juvenile wood of black locust varied between $3.9 \%$ and $6.1 \%$ that was distinctly higher amount than determined in spruce clones of the present study.

Phenolic extractives in ray parenchyma and epithelial cells of a resin canal showed significantly higher UVabsorbance ( $\operatorname{abs}_{280 \mathrm{~nm}} 0.68$ to 0.78 ) as compared to the cell wall associated lignin (Figure 5). UMSP method was also used by Koch et al. [44] to detect phenolic extractives in wooden tissues. It is known (e.g. [16]) that the phenolic compounds are generally synthesised by parenchyma cell in situ. The major types of phenolic extractives found in spruce are lignans, resin acids, sterols and their esters [45]. In our study, an exact identification of the compounds was not possible by using cellular UV microspectrophotometry.

No significant difference $(\mathrm{p}>0.05)$ was determined between individual fungal species and weight loss of spruce clones (Table 2). In general, all spruce clones were extensively degraded by brown rot fungi showing low natural durability (class 4 to 5, EN 350-2 [21]). 
We found that 31-years-old spruce clones mainly contained sapwood that possessed lower density and content of extractives than mature wood. We did not observe pronounced difference between sapwood and heartwood in spruce stems coloured with Bromcresolgreen solution. For example, study [46] of fungicidal activities of Malaysian teak (Tectona grandis) wood extractives showed that acetone-water extract of heartwood was toxic against fungi while acetone-water extractives of sapwood were only fungistatic indicating that toxic compounds accumulated in heartwood during the transformation of sapwood into heartwood.

Another aspect of natural durability is the performance of decay resistance in standardized laboratory and field tests and in real outdoor wooden structures. The ability of wood to absorb moisture has an important effect upon its service life in above ground contact. Service life in these conditions depends on both durability class and treatability class. EN 350-2 [21] indicates that wood of a given durability with low moisture absorbance (treatability) will last markedly longer in above ground conditions, than a wood of the same durability, but with higher water absorbance. Kutnik et al. [47] observed that both the sapwood and heartwood of Douglas fir (durability class 3, moderately resistant) performed better in real outdoor conditions than predicted by standardized tests and demonstrated that knowledge of how a wooden product should be manufactured and assembled is the key challenge to optimizing its service life.

We assume that use of spruce clones in outdoor applications could be limited because of its low decay resistance. Appropriate wood preservation methods should be chosen to prolong its outdoor performance. According to EN 350-2 [21], spruce conforms to the treatability class 3 - 4 (difficult to treat). Consequently, impregnation of spruce wood is problematic because of the reduced permeability, which is affected by the moisture content, drying process and various physical and chemical properties [48]. The aspiration of bordered pits, their size and amount of latewood are the major factors, which influence the permeability of spruce wood [49]. Accordingly, an alternative protection of spruce timber could imply wood hydrothermal modification (HTM) [50]. Further study will be carried out to test HTM spruce regarding its fungal resistance as well as changes in physical and chemical properties after hydrothermal modification in order to find the most appropriate treatment regime.

\section{CONCLUSIONS}

The Norway spruces clones in general displayed low durability against brown rot fungi.

Natural durability of spruce clones did not correlate with stem diameter, density, content of lignin and extractives.
Spruce clones were of juvenile age and, consequently, contained more sapwood with lower density and content of extractives.

It is suggested to use the spruce wood for interior structures. To improve the resistance of spruce wood against biodegradation and to extend its service life in outdoor conditions, additional protection measures, for instance, hydrothermal modification should be applied.

\section{ACKNOWLEDGEMENTS}

The present study was funded by the ESF project "Importance of Genetic Factors in Formation of Forest Stands with High Adaptability and Qualitative Wood Properties" (No. 2009/0200/1DP/1.1.1.2.0/09/APIA/ VIAA/146). We acknowledge Prof. A. Treimanis (LS IWC, Latvia) for careful reading of the manuscript and valuable comments. We greatly thank M. Skute and L. Vikele (LS IWC, Latvia) for performing the chemical analyses. The technical assistance of Mrs. T. Potsch (vTI, Hamburg) in preparing the microscopic sections for UMSP is gratefully acknowledged. Publication fee for this article is provided by European Regional Development Fund project No. 2DP/2.1.1.2.0/10/APIA/VIAA/ 021.

\section{REFERENCES}

[1] Goodell, B., Nicholas, D.D. and Schultz, T.P. (2003) Wood deterioration and preservation. American Chemical Society (ACS), Washington DC. doi:10.1021/bk-2003-0845

[2] Schmidt, O. (2006) Wood and tree fungi. Springer-Verlag, Berlin, Heidelberg.

[3] Irbe, I., Andersons, B., Chirkova, J., Kallavus, U., Andersone, I. and Faix, O. (2006) On the changes of pinewood (Pinus sylvestris L.) chemical composition and ultrastructure during the attack by brown-rot fungi Postia placenta and Coniophora puteana. International Biodeterioration and Biodegradation, 57, 99-106. doi:10.1016/j.ibiod.2005.12.002

[4] Irbe, I., Andersone, I., Andersons, B., Noldt, G., Dizhbite, T., Kurnosova, N., Nuopponen, M. and Stewart, D. (2011) Characterisation of initial degradation stage of Scots pine (Pinus sylvestris L.) sapwood after attack by brown-rot fungus Coniophora puteana. Biodegradation, 22, 719728. doi:10.1007/s10532-010-9449-6

[5] Vance, C.P., Kirk, T.K. and Sherwood, R.T. (1980) Lignification as a mechanism of disease resistance. Annual Review of Phytopathology, 18, 259-288. doi:10.1146/annurev.py.18.090180.001355

[6] Humar, M., Fabcic, B., Zupancic, M., Pohleven, F. and Oven, P. (2008) Influence of xylem growth ring width and wood density on durability of oak heartwood. International Biodeterioration and Biodegradation, 62, 368371. doi:10.1016/j.ibiod.2008.03.010

[7] Aloui, F., Ayadi, N., Charrier, F. and Charrier, B. (2004) Durability of European oak (Quercus petraea and Quercus robur) against white rot fungi (Coriolus versicolor): Relations with phenol extractives. Holzals Rohund Werkstoff, 
62, 286-290.

[8] Gierlinger, N., Jacques, D., Grabner, M., Wimmer, R., Schwanninger, M., Rozenberg, P. and Paques, L.E. (2004) Colour of larch heartwood and relationships to extractives and brown-rot decay resistance. Trees, 18, 102-108. doi:10.1007/s00468-003-0290-y

[9] Duenisch, O., Richter, H.G. and Koch, G. (2010) Wood properties of juvenile and mature heartwood in Robinia pseudoacacia L.. Wood Science and Technology, 44, 301313. doi:10.1007/s00226-009-0275-0

[10] Venalainen, M., Harju, A.M., Saranpää, P., Kainulainen, P., Tiitta, M. and Velling, P. (2004) The concentration of phenolics in brown-rot decay resistant and susceptible Scots pine heartwood. Wood Science and Technology, 38, 109-118. doi:10.1007/s00226-004-0226-8

[11] Hovelstad, H., Leirset, I., Oyaas, K. and Fiksdahl, A. (2006) Screening analyses of pinosylvin stilbenes, resin acids and lignans in Norwegian conifers. Molecules, 11, 103-114. doi:10.3390/11010103

[12] Rayner, A.D.M. and Boddy, L. (1988) Fungal decomposition of wood. Wiley \& Sons, New York.

[13] Eaton, R.A. and Hale, M.D.C. (1993) Wood, decay, pest and protection. Chapman and Hall, London.

[14] EN 335-1 (2006) Durability of wood and wood-based products. Definition of hazard classes of biological attack -Part 1: General. European Committee for Standardization (CEN), Brussels.

[15] Flæte, P.O., Alfredsen, G. and Evans, F.G. (2011) Natural durability of wood tested in different environments in Northern Europe. Document IRG/WP 11-10747, IRG Secretariat, Stockholm.

[16] Hillis, W.E. (1987) Heartwood and tree exudates. SpringerVerlag, Berlin. doi:10.1007/978-3-642-72534-0

[17] Ko, J.H., Yang, J., Oh, S., Park, S. and Han, K.H. (2004) Genomics of wood formation. In: Kumar, S. and Fladung, M., Eds., Molecular Genetics and Breeding of Forest Trees, Food Products Press, An Imprint of The Haworth Press Inc., New York, London, Oxford, 113-140.

[18] Pallardy, S.G. (2008) Physiology of woody plants. Academic Press imprint of Elsevier, Burlington.

[19] Elowson, T., Bergstrom, M. and Hamalainen, M. (2003) Moisture dynamics in Norway spruce and Scots pine during nine years of outdoor exposure above ground in relation to different surface treatments and handling conditions. Holzforschung, 57, 219-227. doi:10.1515/HF.2003.032

[20] Rydell, A., Bergstrom, M. and Elowson, T. (2005) Mass loss and moisture dynamics of Scots pine (Pinus sylvestris) exposed outdoors above ground in Sweden. Holzforschung, 59, 183-189. doi:10.1515/HF.2005.029

[21] EN 350 (2000) Durability of wood and wood-based products - Natural durability of solid wood-Part 1: Guide to the principles of testing and classification of the natural durability of wood. Part 2: Guide to natural durability and treatability of selected wood species of importance in Europe. European Committee for Standardization (CEN), Brussels.

[22] Raberg, U., Edlund, M-L., Terziev, N. and Land, C.J.
(2005) Testing and evaluation of natural durability of wood in above ground conditions in Europe-An overview. Journal of Wood Science, 51, 429-440.

[23] EN 113 (2000) Wood preservatives. Method of test for determining the protective effectiveness against wood destroying basidiomycetes. European Committee for Standardization (CEN), Brussels.

[24] Sandermann, W., Hausen, B. and Simatupang, M. (1967) Orientierende versuche zur differenzierung von splint und kern sowie zum sichtbarmachen der uebergangszone von fichte und anderen nadelhölzern. Das Papier Jahrgang, 21, 349-354.

[25] DIN 50014-20/65-1 (1985) Climates and their technical application. Deutsches Institut für Normung, Berlin.

[26] DIN 68364 (1979) Testing of wood; determination of density. Deutsches Institut für Normung, Berlin.

[27] Browning, B.L. (1967) Methods of wood chemistry. Vol. I. Wiley \& Sons, Interscience Publishers, New York.

[28] TAPPI T280 pm-99 standard (2000) Acetone extractives of wood and pulp. Technical Association of the Pulp and Paper Industry, TAPPI Press, USA.

[29] Spurr, A.R. (1969) A low-viscosity epoxy resin embedding medium for electron microscopy. Journal of Ultrastructural Research, 26, 31-43. doi:10.1016/S0022-5320(69)90033-1

[30] Koch, G. and Kleist, G. (2001) Application of scanning UV microspectrophotometry to localise lignins and phenolic extractives in plant cell walls. Holzforschung, 55, 563-567. doi:10.1515/HF.2001.091

[31] Koch, G. and Grünwald, C. (2004) Application of UV microspectrophotometry for the topochemical detection of lignin and phenolic extractives in wood fibre cell walls. In: Schmitt, U., Ed., Wood Fibre Cell Walls: Methods to Study Their Formation, Structure and Properties, Swedish University of Agricultural Sciences, Uppsala, 119130.

[32] Bergstrom, M., Rydell, A. and Elowson, T. (2004) Durability of untreated Norway spruce (Picea abies) exposed outdoors above ground for nine years. Holzforschung, 58, 167-172. doi:10.1515/HF.2004.025

[33] Fengel, D. and Wegener, G. (2003) Wood-Chemistry, ultrastructure, reactions. Verlag Kessel, Remagen.

[34] Harju, A.M., Venalainen, M., Anttonen, S., Viitanen, H., Kainulainen, P., Saranpää, P. and Vapaavuori, E. (2003) Chemical factors affecting the brown-rot decay resistance of Scots pine heartwood. Trees, 17, 263-268.

[35] Lange, P.W. (1954) The distribution of the components in the plant cell walls. Svensk Papperstidn, 57, 563-567.

[36] Fergus, B.J., Procter, A.R., Scott, A.N. and Goring, D.A.I. (1969) The distribution of lignin in spruce-wood as determined by ultraviolet microscopy. Wood Science and Technology, 3, 117-138. doi:10.1007/BF00639636

[37] Fergus, B.J. and Goring, D.A.I. (1970) The location of guaiacyl and syringyl lignins in birch xylem tissue. Holzforschung, 24, 113-117. doi:10.1515/hfsg.1970.24.4.113

[38] Musha, Y. and Goring, D.A.I. (1975) Distribution of syringyl and guaiacyl moieties in hardwoods as indicated 
by ultraviolet microscopy. Wood Science and Technology, 9, 45-58. doi:10.1007/BF00351914

[39] Fujii, T., Shimizu, K. and Yamaguchi, A. (1987) Enzymatic saccharification on ultra thin sections and ultraviolet spectra of Japanese hardwoods and softwoods. Mokuzai Gakkaishi, 33, 400-407.

[40] Sander, C. and Koch, G. (2000) Effects of acetylation and hydrothermal treatment on lignin as revealed by cellular UV-spectroscopy in Norway spruce (Picea abies (L.) Karst.). Holzforschung, 85, 1-6.

[41] Koch, G., Rose, B., Patt, R. and Kordasachia, O. (2003b) Topochemical investigations on delignification of Picea abies (L.) Karst. during alkaline sulfite (ASA) and bisulfite pulping by scanning UV microspectrophotometry. Holzforschung, 57, 611-618. doi:10.1515/HF.2003.092

[42] Saranpää, P., Vapaavuori, E. and Peltola, H. (2000) Effect of forest management on wood quality. In: Paavilainen, L., Ed., Metsaalan Tutkimusohjelma, Wood Wisdom, Vuosikirja 1999, Raportti 2/2000, 178-185.

[43] Fagerstedt, K., Ritschkoff, A.C. and Saranpää, P. (2005) Natural variations in the amount of lignin in Norway spruce: Can lignin be modified to change the properties of wood products? In: Jalkanen, A. and Nygren, P., Eds., Sustainable Use of Renewable Natural Resources-From Principles to Practices, University of Helsinki, Department of Forest Ecology Publications, 34, 1-7.

[44] Koch, G., Puls, J. and Bauch, J. (2003a) Topochemical characterization of phenolic extractives in discoloured beechwood (Fagus sylvatica L.). Holzforschung, 57, 339345. doi:10.1515/HF.2003.051
[45] Ekmann, R. and Holmbom, B. (2000) The chemistry of wood resin. In: Back, E.L. and Allen, L.H. Eds., Pitch Control, Wood Resin and Deresination, TAPPI Press, Atlanta, 37-76.

[46] Niamke, F.B., Amusant, N., Lemenager, N., Chaix, G., Thévenon, M.F., Baudasse, C., Kati-Coulibaly, S., Adima, A.A., Ado, I.G. and Jay-Allemand, C. (2011) Decay resistance attributes of teak (Tectona grandis L. f.) wood: Comparison of the fungicidal activities of quinines. Document IRG/WP 11-10752, IRG Secretariat, Stockholm.

[47] Kutnik, M., Lepetit, S. and Le Neve, S. (2011) Performances of Douglas fir in real outdoor use conditions. Document IRG/WP 10-20472, IRG Secretariat, Stockholm.

[48] Ulvcrona, T., Lindberg, H. and Bergsten, U. (2006) Impregnation of Norway spruce (Picea abies L. Karst.) wood by hydrophobic oil and dispersion patterns in different tissues. Forestry, 79, 123-134. doi:10.1093/forestry/cpi064

[49] Usta, I. and Hale, M.D. (2006) Comparison of the bordered pits of two species of spruce (Pinaceae) in a green and kiln-dried condition and their effects on fluid flow in the stem wood in relation to wood preservation. Forestry, 79, 467-475. doi:10.1093/forestry/cp1011

[50] Andersons, B., Andersone, I., Biziks, V., Irbe, I., Chirkova, J., Sansonetti, E., Grinins, J. and Militz, H. (2010) Hydrothermal modification for upgrading the durability properties of soft deciduous wood. Document IRG/WP 10-40494, IRG Secretariat, Stocholm. 